\title{
Georges Gilles de la Tourette (1857-1904)
}

\author{
Olivier Walusinski · Julien Bogousslavsky
}

Received: 5 September 2010/Revised: 4 October 2010/Accepted: 8 October 2010/Published online: 27 October 2010 (c) Springer-Verlag 2010

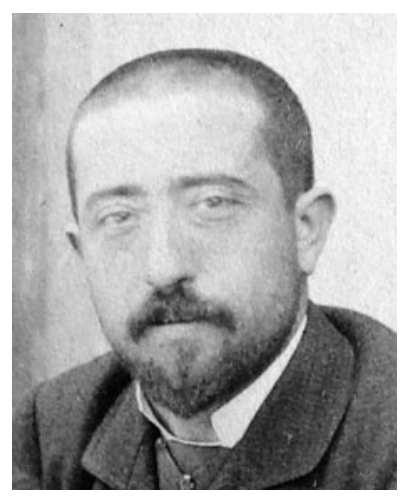

Georges Gilles de la Tourette, a neurologist and prolific medical writer at the end of the nineteenth century, belonged to a group of students closest to Jean-Martin Charcot (1825-1893). Charcot writes in a preface [5]: "Gilles de la Tourette says that he contented himself with explaining my teaching and organising my works and those of my pupils. It is the first time he has forgotten he is one of my pupils, and one of the best. He does not mention his own works, which are of the highest importance in their domain."

\footnotetext{
O. Walusinski ( $\square)$

Family Physician, Private Practice, 20 Rue de Chartres, 28160 Brou, France

e-mail: walusinski@baillement.com

J. Bogousslavsky

Department of Neurology and Neurorehabilitation,

Clinique Valmont, Genolier Swiss Medical Network,

1823 Glion/Montreux, Switzerland

e-mail: jbogousslavsky@valmontgenolier.ch
}

Georges Gilles de la Tourette was born on 30 October 1857 in a small village near Loudun in west-central France. His father was a merchant but belonged to a family of physicians. Georges lacked discipline and had a difficult character with unpredictable mood swings. He was peculiar, but exhibited a keen intelligence [4]. He enrolled in medical school in Paris at the age of 20 years, 3 years after having begun his studies at the medical school in Poitiers. In 1881, he became an interne (house officer) at the Paris public hospitals. In 1884, he started studying under J. M. Charcot (1825-1893), rapidly becoming one of his favourite pupils, advancing to the rank of chef de clinique (specialist registrar) for 2 years (1887-1888) [6, 10].

Although it is not clear why, Gilles de la Tourette was interested in chorea well before meeting Charcot. Indeed, as early as 1881 , he translated the 1880 historical paper by the American physician George Beard (1839-1883) on the Jumping Frenchmen of Maine. Charcot encouraged his pupil to persist in these studies. This first description appeared in 1885 in Les Archives de Neurologie: "Étude sur une affection nerveuse caractérisée par de l'incoordination motrice accompagnée d'écholalie et de coprolalie" (Study of a nervous condition characterised by motor incoordination accompanied by echolalia and coprolalia), in which he included the case of the Marquise de Dampierre, initially published by J. Itard (1774-1838) in 1825 [7]. We should note that his article was published 1 year before he defended his doctoral dissertation in 1886. Except for one occasion in 1899, when another clinical case was described in La Semaine Médicale, Gilles de la Tourette never again published on the convulsive tic disorder that would eventually be named after him. In the Semaine Médicale of 15 September 1886, Charcot clarified the distinction between chorea and convulsive tic disorder, writing: "We have proved that these people have what 
I would call a particular form of mental alienation ..." [3]. "We" may mean "Gilles de la Tourette and I", but may also be the emphatic "we" meaning "I", indicating Charcot's significant role in this description. But given that "his" anatomical-clinical method had not been used, since these patients had no detectable neurological lesions, he preferred to attribute the description to one of his pupils $[6,8,9]$.

From 1884 to 1887 , Gilles de la Tourette became intrigued by hysteria, zealously compiling the experiments and theories passed on by his teacher, who had been focusing on the topic since 1870 . "In 1884, becoming an interne at La Salpêtrière, I was already thinking of becoming the transmitter of the doctrine put forward by our eminent master on hysteria" (L'hypnotisme et les états analogues au point de vue médico-légal, p. XII). "The teaching of our master had supplied us the enduring basis" $[6,8,9]$.

When he arrived at La Salpêtrière, Gilles de la Tourette had published a historical biography of Théophraste Renaudot, also from the Poitou region and the initiator of print media under Richelieu and Louis XIII in 1631. His passion for the press led him to work with a journalist at L'Eclair and Le Temps, Octave Lebesgue, also known as G. Montorgueil (1857-1933), to whom he confidentially provided information on the experiments at La Salpêtrière, before this information became widely available, in order to increase the work's notoriety and dissemination. In the medical field, in 1888, he helped create the La Nouvelle Iconographie de La Salpêtrière, for which he wrote several articles until 1900 [2, 4, 9, 10]. After 1889, he added a private practice (39 rue de l'Université, Paris) to his hospital appointment and organised public lectures on literary and theatrical topics [8].

The year 1893 began well for him. He became a hospital physician and was awarded with the Légion d'honneur. But soon afterwards, he lost one of his sons to meningitis. Then his venerated teacher Charcot died in August. At the end of this cruel year, a patient came to his home and fired a gun at him. She accused him of making her incapable of earning her living after the hypnosis she underwent at $\mathrm{La}$ Salpêtrière $[2,9,10]$.

Gilles de la Tourette had been A. Fournier's interne and was reluctant to accept this former chief's findings on the syphilitic origin of tabes. His book Les myélites syphilitiques, published in 1899, dealt with this subject. As the sad irony of history would have it, Gilles de la Tourette died in 1904 after spending 3 years in a Swiss mental institution following general paralysis, the syphilitic origin of which he had refuted [8-10]. His behavioural problems dated back at least 4 years and had been reported in the press. $L a$ Gazette Médicale wrote: "This neuropathologist continued to see patients until the day his family found him completely naked, flailing wildly before a terrified patient hiding behind some furniture in the doctor's office where he had come to consult about ... his health" [1]. Mrs. Gilles de la Tourette tended to her husband until the end, with support from his colleagues and friends, J.B. Charcot and E. Brissaud [4, 10]. A.J. Lees has written: "Despite this abrasive and capricious temperament Gilles de la Tourette gained considerable respect from a number of his pupils" [8].

\section{References}

1. Anonymous (1904) Obituary: Gilles de la Tourette. Gazette Médicale de Paris 13:269-270

2. Bogousslavsky J, Walusinski O (2010) Gilles de la Tourette's criminal women: the many faces of fin de siècle hypnotism. Clin Neurol Neurosurg; 112:549-551

3. Charcot JM (1886) Hystérie et tics; diagnostic. La Semaine Médicale: 6:363-364

4. Duncan G (1995) Gilles de la Tourette: aspects connus et méconnus de sa vie et de son oeuvre. Doctoral dissertation in medicine. Université de Poitiers, Faculté de Médecine et de Pharmacie, 166pp (French)

5. Gilles de la Tourette G (1891-1893) Traité clinique et thérapeutique de l'hystérie d'après l'enseignement de La Salpêtrière. Plon, Nourrit \& Cie, Paris, vol 3

6. Guilly P (1982) Gilles de la Tourette. In: Clifford Rose F, Bynum WF (eds) Historical aspects of neurosciences. Raven Press, New York, pp 397-413

7. Kushner H (1999) A cursing brain? The histories of Tourette syndrome. Harvard University Press, Cambridge, p 313

8. Lees A (1986) Georges Gilles de la Tourette: the man and his time. Rev Neurol (Paris) 142:808-816

9. Legendre P (1905) Gilles de la Tourette, 1857-1904. Bulletins et Mémoires de la Société Médicale des Hôpitaux de Paris 21:1298-1311

10. Walusinski O, Duncan G (2010) Living his writings: the example of neurologist G. Gilles de la Tourette. Mov Disord. (in press) 